\title{
УПРОВАДЖЕННЯ ІНТЕРАКТИВНИХ МЕТОДІВ НАВЧАННЯ В КОНТЕКСТІ ФОРМУВАННЯ ІНФОРМАЦЙНОЇ КУЛЬТУРИ МАЙБУТНІХ ФАХІВЦІВ ФІСКАЛЬНОЇ (ПОДАТКОВОЇ) СЛУЖБИ
}

Гладченко О. В. Упровадження інтерактивних методів навчання в контексті формування інформаційної культури майбутніх фахівців фіскальної (податкової) служби.

Автор статті на основі узагальнення наукових надбань щодо використання інтерактивних методів у теорії та практиці професійної освіти окреслює значущість упровадження методу проектів, кейс-методу, методу «Дельфі», портфоліо, навчання в малих групах, ділової гри в контексті формування інформаційної культури майбутніх фахівців державної фіскальної (податкової) служби.

Ключові слова: інформаційна культура, інтерактивний процес, інтерактивні методи, майбутній фахівець державної фіскальної (податкової) служби, метод проектів, кейс-метод, метод «Дельфі», портфоліо, навчання в малих групах, ділова гра.

Гладченко О. В. Внедрение интерактивных методов обучения в контексте формирования информационной культуры будущих специалистов фискальной (налоговой) службы.

Автор статьи на основе систематизации научных достижений в использовании интерактивных методов в теории и практике профессионального образования определяет значимость внедрения метода проектов, кейс-метода, метода «Дельфи», портфолио, обучения в малых группах, деловой игры в контексте формирования информационной культуры будущих специалистов государственной фискальной (налоговой) службы.

Ключевые слова: информационная культура, интерактивный процесс, интерактивные методы, будущий специалист государственной фискальной (налоговой) службы, метод проектов, кейс-метод, метод «Дельфи», портфолио, обучение в малых группах, деловая игра.

Gladchenko O. Implementation of the interactive teaching methods into the context of forming the informational culture of the future Tax Service specialists.

Taking as the basis the synthesis of scientific achievements on the use of interactive methods in the theory and practice of vocational education the author outlines the importance of the implementation of the project method, case method, «Delphi», portfolio, training in small groups, business games in the context of forming the informational culture of the future specialists of the state tax service.

Key words: informational culture, interactive process, interactive methods, future professional of the state tax service, project method, case method, «Delphi», portfolio, training in small groups, business games.

Упровадження інтерактивних методів навчання в контексті формування інформаційної культури майбутнього фахівця державної фіскальної (податкової) служби зумовлено необхідністю встановлення органічного зв'язку між теорією й практикою професійної підготовки студента шляхом навчання, спрямованого на 
практичне застосування знань, аналіз конкретних ситуацій, розв'язання професійних проблем тощо. Практична діяльність фахівця вимагає перетворення знань: по-перше, вони повинні бути актуалізовані й об'єднані навколо певної проблеми, що має складний і цілісний характер; по-друге, мають бути синтезовані й переведені на мову практичних дій, тобто постати засобом розв'язання реальних практичних професійних завдань.

Проблему інтерактивності досліджують науковці різних професійних царин (Л. Галіцина, М. Кларін, В. Мельник, С. Сисоєва, Л. Шелестова та ін.).

Поняття «інтерактивність» витлумачується як учіння, що грунтується на взаємодії [3, с. 31-32]; спеціально організована пізнавальна діяльність, що має яскраво виражену практичну спрямованість [1, с. 248].

Відповідно, інтерактивне навчання - це спеціальна форма організації пізнавальної діяльності, яка має конкретну, передбачувану мету - створення комфортних умов навчання, за яких кожен студент відчуває свою успішність та інтелектуальну спроможність [2, с. 103]. Особливістю інтерактивного навчання $\epsilon$ організація навчального процесу, що здійснюється за умови постійної активної взаємодії. Тому, аналізуючи власні дії та дії партнерів, учасники навчального процесу змінюють модель поведінки, більш усвідомлено засвоюють знання та вміння.

Метою статmі є визначення значущих інтерактивних методів навчання майбутніх фахівців фіскальної служби (податківців) у контексті формування інформаційної культури.

У 80-х роках ХХ століття Національним тренінговим центром у США (штат Меріленд) проведено дослідження із використання інтерактивних методів у галузі вищої освіти, які є свідченням того, що інтерактивні методи зумовлюють збільшення відсотків засвоєння отриманої інформації, оскільки впливають не лише на свідомість учасників, а й на їхні почуття та волю. У процесі досліджень Національного тренінгового центру визначено такі результати застосування пасивних (лекція 5\%, читання 10\%) та інтерактивних (відео 20\%, демонстрації 30\%, дискусійні групи 50\%, практика $75 \%$ ) методів.

Згідно із позицією Т. Цюман, в інтерактивному процесі відбувається не навчальне заняття за конкретною темою, а розгортається «саме життя», де учасники «проживають» конкретну, сплановану, структуровану, концентровану подію [9, с. 103].

Поділяємо позицію С. Сисоєвої, яка виокремлює такі основні переваги інтерактивного навчання:

- інтерактивне навчання підвищує мотивацію, дає емоційний поштовх до пошукової активності суб'єктів навчання, спонукає їх до конкретних дій, формує здатність неординарного мислення;

- інтерактивна діяльність забезпечує не тільки приріст умінь, навичок, способів діяльності й комунікації, але й $є$ необхідною умовою становлення й удосконалення професійної компетентності шляхом залучення учасників освітнього процесу до осмисленого переживання індивідуальної й колективної діяльності для набуття досвіду, усвідомлення та прийняття цінностей;

- інтерактивні технології навчання дозволяють інтенсифікувати процес розуміння, засвоєння й творчого застосування знань під час розв'язання практичних завдань [8, с. 38-39].

Установлено, що у психолого-педагогічній літературі часто застосовується поняття «інтерактивні технології», яке науковці по-різному класифікують. Проте, на основі аналізу літератури можна виокремити підходи, до яких належать будь-які 
заняття діалогічної взаємодії: інтерактивні технології визначаються як ділові ігри; інтерактивні технології ототожнюються 3 заняттями нестандартної форми; до інтерактивних технологій відносять тренінгові заняття [3; 5; 11].

Дослідник проблеми застосування інтерактивних форм роботи М. Кларін класифікує їх за кількома ознаками, основою яких уважає принцип активності. Першою ознакою інтерактивних форм роботи науковець назвав фізичну активність це зміна робочого місця, запис, малювання тощо. Другою ознакою - соціальну активність, яка дозволяє досягнути результату через постановку питань одного учасника групи іншому тощо. Третьою ознакою $є$ пізнавальна активність доповнення учасниками викладеного матеріалу, виступ як джерело професійного досвіду, самостійний пошук розв'язання проблеми [4, с. 32].

Поняття інформаційної культури податківця сучасні дослідники інтерпретують як складник загальної культури, правові норми професійної діяльності, правила поведінки, мотивацію особистості у сфері податкового управління, комунікативність спілкування в інформаційному, комп'ютерному суспільстві, 3 використанням Інтернету, у задоволенні з боку тих, хто сплачує податки, і задоволеності тих, хто отримує результати цієї праці, тобто працівників податкової служби [10]; уміння швидко, правильно, достатньо підібрати необхідну інформацію, доступно та етично іiі донести до платника, що унеможливить виникнення конфліктної ситуації [7, с. 207].

У нашому розумінні інформаційна культура податківця $є$ складником загальної культури особистості, інтегративною властивістю фахівця щодо володіння системним і прикладним програмним забезпеченням, своєчасності й доцільності застосування інформаційно-комунікаційних технологій для вирішення виробничих завдань на засадах професійної етики [2, с. 55].

3 урахуванням вищеокресленого вважаємо за доцільне формувати інформаційну культуру майбутніх працівників фіскальної служби (податківців) шляхом використання в навчальному процесі таких активних методів: метод проектів, кейс-метод, метод «Дельфі», портфоліо, навчання в малих групах, ділова гра.

Подамо змістове наповнення вказаних методів.

Упровадження інтерактивних методів навчання 3 урахуванням контексту професійної діяльності працівника фіскальної (податкової) служби здійснюється у навчальній і позанавчальній діяльності студентів.

Організація інтерактивного навчання передбачає спільне розв'язання проблем, які за змістом максимально наближені до специфіки професійної діяльності, сприяють не тільки розвитку самостійності та пошукової активності студентів, а й формують особливу атмосферу спілкування, що $\epsilon$ невід'ємним складником культури особистості. Особливістю запровадження таких методів $€$ компетентнісна спрямованість, що уможливлює розвиток ключових професійних компетентностей i компетенцій.

3-поміж інтерактивних методів акцентуємо на методах колективної творчості (мозкова атака, метод ключових питань та вільних асоціацій), використання яких сприяє розвитку творчого мислення студентів, інтеграції та диференціації отриманих знань відповідно до розв'язання проблемної ситуації.

Так, методи мозкової атаки та вільних асоціацій доречні під час колективного обговорення проблем загальнопрофесійного характеру («Світові тенденції розбудови інформаційного суспільства», «Основні складники інформаційної сфери органів державної фіскальної (податкової) служби», «Специфіка інформаційних відносин у діяльності органів державної фіскальної (податкової) служби» тощо). 
Метод ключових питань запроваджується в навчальний процес під час аналізу вузькопрофесійних проблем, пов'язаних 3 інформаційною культурою майбутнього фахівця. Наприклад, семінар «Інформаційна безпека як складник інформаційної культури фіскальних (податкових) відносин» передбачає обговорення питання сутності інформаційної безпеки діяльності органів державної фіскальної (податкової) служби. У результаті різних міркувань визначено змістове поняття «інформаційна безпека».

Із-поміж інтерактивних методів навчання, професійної підготовки фахівців чільне місце посідає метод випадків, ситуацій - кейс-метод (case-study), запровадження якого дозволяє органічно поєднувати теорію 3 практикою, реалізовувати компетентнісний підхід у навчанні.

Метод кейс-стаді забезпечує участь кожного зі студентів в обговоренні, дає змогу висловити певну позицію, активізує індивідуальну мисленнєву та пізнавальну діяльність учасників; спонукає до виникнення роздумів, дискусій; самостійного пошуку способу розв'язання суперечностей. Для нас значущим $є$ те, що кейс-стаді припускає поєднання різноманітних методів роботи в малих групах: обмін думками, докладне обговорення, мозкову атаку, мета-план, дискусію для прийняття остаточних рішень, оскільки в більшості випадків містить суперечливі аспекти, які змушують продуктивніше мислити та приймати самостійні рішення.

У контексті нашого доробку під кейс-стаді розуміємо різновид професійно орієнтованих завдань, що характеризується певними процесуальними ознаками, зумовленими специфічними для конкретної професійної події змістом, спрямованих на формування вміння оцінювати конкретну ситуацію та будувати відповідно до засвоєних у процесі навчання типізованих алгоритмів програмових професійних дій із використанням інформаційних технологій, адекватних певній ситуації.

Розбір кейса проходить у малій групі (3-6 осіб). У процесі аналізу ситуації студенти здійснюють оцінку, встановлюють умови, причини, наслідки розгортання, обмінюються думками, здійснюють діагностування змісту діяльності, розробляють програму діяльності, прогнозують потенційне розв'язання проблеми, розробляють рекомендації. По завершенню роботи учасники групи презентують пропозиції.

Так, використання методу кейс-стаді надало змогу студентам не тільки визначитись щодо доцільності використання відповідних інформаційних технологій для розв'язання практичних ситуацій, а й навчитися працювати в команді, формулювати питання, аргументувати відповіді, активно структурувати ідеї, виявляти ініціативу, планувати дії й передбачати наслідки.

Оцінювання роботи студентів на практичних заняттях із застосуванням ситуаційних вправ (кейс-стаді) здійснюється на основі розробленої карти оцінювання, у якій для кожного студента розписані критерії та відповідна кількість балів, що нараховуються за виконання певного виду роботи.

Значну увагу під час викладання курсу приділено самостійній роботі студентів. До модуля «Особливості розвитку інформаційної культури працівника фіскальної (податкової) служби» студенти розробляють розгорнуті плани занять, ігрові програми, визначають найбільш складні ситуації в контексті спілкування 3 клієнтами, ведення електронної документації тощо.

Оскільки професійна підготовка майбутніх працівників державної фіскальної (податкової) служби здійснюється в галузі знань «Економіка і підприємництво», розроблено практичні завдання, спрямовані на формування в них умінь та навичок, необхідних для здійснення загальнопрофесійних видів економічної діяльності: 
- вивчення інструментальних можливостей табличного процесора MS Excel для розв'язання завдань менеджменту й економічного аналізу задля забезпечення здатностей здійснювати оброблення, аналітичну інтерпретацію економічної інформації та іiі узагальнення; оперативно змінювати значні масиви економічної інформації за часового обмеження; використовувати сучасні методи діагностики та експертизи економічної діяльності, аналізувати основні економічні показники діяльності підприємства 3 використанням сучасних методик й урахуванням інфляції та конвертованості національної валюти; планувати потреби в матеріальних, фінансових і трудових ресурсах із застосовуванням сучасних методик та економікоматематичних моделей;

- вивчення можливостей інтегрованого пакета MS Office для роботи 3 електронними офісними документами різного рівня складності та типу (текстовими документами, розрахунковими таблицями, базами даних) і сумісного використання даних для забезпечення здатностей: сприяння створенню сучасної інформаційної бази та впровадженню сучасних інформаційних систем i технологій у практику економічної діяльності підприємств; ефективне використання можливостей автоматизованого робочого місця спеціаліста; розроблення на основі інформаційного забезпечення та комп'ютерних технологій альтернативних варіантів рішень;

- вивчення можливостей комп'ютерних мереж та Інтернет задля здійснення електронного документообігу на основі організації розподіленого оброблення даних у локальних та глобальних мережах, ведення електронної комерції, реклами та мережевої взаємодії з партнерами, створення та розміщення в мережі Інтернет гіпертекстових документів для формування вмінь: забезпечення функціонування ефективної мережі інформації, зокрема інформації 3 обмеженим доступом; формування інформаційного забезпечення управління економічною діяльністю організації з використанням різноманітних джерел.

Конкурс «Інформатика i фіскальна (податкова) справа» проведений серед студентів III курсу освітньо-кваліфікаційного рівня «бакалавр» напряму підготовки «Фінанси і кредит», варіативної компоненти «Оподаткування». Спільно зі студентами розроблено сценарний план конкурсу, який передбачав п'ять тематичних зупинок. Кожна 3 них у змістовому аспекті наповнена цікавими запитаннями, інтерактивними методами: студенти розв'язували проблемні завдання, кросворди; складали поетичні рядки, які стосувалися професійних обіцянок майбутнього фіскального працівника (податківця). Конкурсні завдання за своїм змістом дозволили об'єднати питання інформаційної грамотності студентів (інформаційні технології) 3 теорією та практикою інформаційної діяльності майбутнього працівника державної фіскальної (податкової) служби.

Цікавою позанавчальною формою $є$ проведення інтелектуального конкурсу «Брейн-ринг», сценарний план якого розроблявся викладачами факультету економіки та оподаткування спільно зі студентами. Ураховуючи те, що інформаційна культура майбутнього фахівця державної фіскальної (податкової) служби $є$ складником загальної культури, зміст цього інтелектуального змагання охоплював не тільки професійні питання, а й ті, що стосувалися світогляду студентів. Поєднання навчальної й позанавчальної роботи щодо формування операційно-діяльнісного компонента інформаційної культури майбутніх фіскальних працівників (податківців) дозволяє не тільки розширювати інформаційний тезаурус знань функціональних можливостей комп'ютерної техніки, а й розвивати їхні професійні компетенції.

Оскільки професійна практика проходить у VIII семестрі та $є$ завершальним 
етапом навчання фахівця освітньо-кваліфікаційного рівня бакалавр напряму підготовки «Фінанси і кредит» варіативної компоненти «Оподаткування», то саме ці інтерактивні методи забезпечують формування операційно-діяльнісного компонента інформаційної культури майбутнього фіскального працівника (податківця). А у процесі практики ці вміння перевіряються та вдосконалюються за реальних виробничих умов.

Комплексне запровадження у процес професійної підготовки майбутніх фахівців фіскальної (податкової) галузі вищеокреслених заходів дозволяє сформувати професійні портфоліо (способу фіксації відповідних результатів). У цьому контексті, як зазначають фахівці, податковий професійний блок охоплює чотири сегменти операційної діяльності державної податкової служби, а саме: реєстрації платників податків; обробки податкової звітності і платежів; обліку платежів; податкового аудиту [6, с. 85].

Готовність до виконання зазначених вище видів діяльності потребує від студентів оволодіння відповідним програмним забезпеченням, умінь і навичок його використання в розв'язанні виробничих завдань. Портфоліо майбутнього працівника податкової служби містить необхідне програмне забезпечення 3 урахуванням основних сфер його операційної діяльності щодо реалізації завдань податкового професійного блоку.

За зростання інформації людина відчуває прискорення життя і максимальну насиченість подіями, що постає дедалі вагомішим стресогенним чинником, який визначається як інформаційний тиск. Стресову ситуацію породжує як постійний надлишок інформації, так і різке зниження іï кількості. Потрібен певний рівень психологічної врівноваженості, який передбачає достатню критичність у засвоєнні неабияких інформаційних пластів, уміння зберігати внутрішній світ, підтримуючи здатність до мисленнєвого діалогу (який виховується завдяки неквапливому читанню і роздумам) замість одночасного прийняття різних позицій. Так, у межах наукової роботи студенти досліджують питання, пов'язані 3 майбутньою професійною діяльністю, інформаційною культурою. Результати досліджень висвітлюються у доповідях на наукових студентських конференціях.

Отже, визначений підхід до змісту та організації навчально-виховного процесу формування інформаційної культури майбутніх фахівців державної фіскальної (податкової) служби за своїм змістовим наповненням та особливостями впровадження в навчальний процес впливатиме на розвиток важливих компонентів професійної підготовки майбутніх фахівців.

\section{Література}

1. Волкова Н. П. Професійно-педагогічна комунікація : [навч. посіб.]/ Н. П. Волкова. - К. : ВЦ «Академія», 2006. - 256 с. 2. Гладченко О. В. Формування інформаційної культури майбутніх фахівців державної податкової служби у процесі професійної підготовки : дис. ... канд. пед. наук : 13.00.04 / Гладченко Оксана Вікторівна. - К., 2013. - 265 с. 3. Ігри дорослих. Інтерактивні методи навчання / упоряд. Л. Галіцина. - К. : Ред. загальнопед. газ., 2005. - 128 с. - (Бібліотека «Шкільного світу»). 4. Кларин М. В. Корпоративный тренинг от А до Я/ М. В. Кларин. - М. : Дело, 2000. - 224 с. 5. Мельник В. В. Інтеракція в освітньому процесі: технологія організації : [навч.-метод. посіб.] / В. В. Мельник. Хмельницький : [б. в.], 2003. - 148 с. 6. Модернізація державної податкової служби України у контексті інноваційного розвитку: матеріали наук.-практ. семінару. Ірпінь : Нац. ун-т ДПС України, 2009. - 286 с. 7. Новицька Н. Б. Інформаційна культура податківця/ Н. Б. Новицька// Професійна етика працівника державної 
податкової служби як складова етики державного службовця України : тези доп. наук.-практ. конф., Ірпінь, 15 груд. 2006 р. - Ірпінь, 2006. - С. 205-208. 8. Сисосва С. О. Інтерактивні технології навчання дорослих : [навч.-метод. посіб.] / С. О. Сисоєва. - К. : ВД «ЕКМО», 2011. - 320 с. 9. Цюман Т. П. Формування культури життєвого самовизначення старшокласників засобами освітнього тренінгу : дис. ... канд. пед. наук : 13.00.05/ Цюман Тетяна Петрівна. - К., 2008. - 221 с. 10. Шамрай В. О. Формування інформаційної культури фахівця податкової служби України [Електронний ресурс] / В. О. Шамрай, А. П. Кошіль, А. І. Жаров // Проблеми впровадження інформаційних систем і технології : тези доп. (V Міжнар. наук.-практ. конф., Ірпінь, 15-17 трав. 2004 р.).- Ірпінь, 2004.- Режим доступу : http://nc.nusta.com.ua/Kyrsi\%202004/tezi/images_tezi/041.htm. - Назва 3 екрана. 11. Шелестова Л. Інтерактивні технології: «за» i «проти» / Л. Шелестова // Шкільний світ. -2003 . - № 12. - С. 3.

УДК 371.134

Роман Горбатюк

\section{ОСОБЛИВОСТІ ПІДГОТОВКИ МАЙБУТНІХ УЧИТЕЛІВ ТЕХНОЛОГІЙ ДО ПРОФЕСІЙНОЇ ДІЯЛЬНОСТІ В СУЧАСНИХ УМОВАХ}

Горбатюк Р. М. Особливості підготовки майбутніх учителів технологій до професійної діяльності в сучасних умовах.

У статті зроблено спробу обгрунтувати особливості підготовки майбутніх учителів технологій до професійної діяльності на основі сучасних інформаційнокомунікаційних технологій. Навчальними планами i кваліфікаційною характеристикою на кожному етапі становлення педагогічних фахівців визначено комплекс психолого-педагогічних, суспільних, загальнотехнічних i спеціальних дисциплін, що у взаємозв'язку формують професійні вміння і навички, розвивають творче мислення студентів.

Ключові слова: вчитель технологій, інформаційно-комунікаційні технології, вміння, навички, підготовка, професійна діяльність.

Горбатюк Р. М. Особенности подготовки будущих учителей технологий в профессиональной деятельности в современных условиях.

В статье сделана попытка обосновать особенности подготовки будущих учителей технологий к профессиональной деятельности на основе современных информационно-коммуникационных технологий. Учебными планами и квалификационной характеристикой на каждом этапе становления педагогических специалистов определен комплекс психолого-педагогических, общественных, общетехнических и специальных дисциплин, которые во взаимосвязи формируют профессиональные умения и навыки, развивают творческое мышление студентов.

Ключевые слова: учитель технологий, информационно-коммуникационные технологии, умения, навыки, подготовка, профессиональная деятельность.

Horbatyuk R. M. The features of training the teachers the technology of professional activities under present circumstances.

This paper is an attempt to justify the features of training future technology teachers the professional activities based on modern information and communication technologies. Curriculum and qualification characteristics at each stage of educational experts are defined, 